\title{
Management, Appraisal and Preservation of Electronic Records: the Belarusian Experience
}

\author{
ANDREI RYBAKOU, PH.D. \\ Director Belarusian Research Institute for Documentation and Archival Science (BelNIIDAD), Minsk, Bela- \\ rus, + 375172867693 \\ e-mail: rybakou@belniidad.by
}

\begin{abstract}
Management, Appraisal and Preservation of Electronic Records: the Belarusian Experience
\end{abstract}
\section{ABSTRACT}

The article is devoted to the new challenges that archives faced during the last twenty years: how to manage E-records, what are the principles and criteria of their appraisal, how to transfer the most valuable E-records to archives and to insure their long-term preservation. The author discovers the solutions of the mentioned problems implemented in the national legislation, reveals the techniques and practices used. In spite of the huge number of legislative acts the problems still remain. The author notes that archivists in their work with Erecords strongly depend upon the hardware and software used for creating and operating E-records, but that does not mean they should stay outside the process. They should feel free to state their demands and to warn about the danger of loss of documents and information if ignored. The quality solutions of the problems are possible only on the basis of close cooperation of records managers, archivists and specialists in the sphere of information technologies.

Key words: electronic record, record in electronic form, records management, appraisal, storage

Gestione, selezione e conservazione dei documenti digitali: l'esperienza della Bielorussia

\section{SINTESI}

L'articolo è dedicato alle nuove sfide che gli archivi hanno affrontato nel corso degli ultimi venti anni: come gestire i documenti digitali, quali sono i principi e i criteri della loro valutazione, come trasferire i più preziosi agli archivi ed assicurare la loro conservazione a lungo termine. L'autore enumera le soluzioni dei problemi menzionati attuate nella legislazione nazionale, e narra le pratiche utilizzate. Nonostante l'enorme numero di atti legislativi, i problemi rimangono ancora. L'autore osserva che gli archivisti nel loro lavoro con i documenti digitali dipendono fortemente dall'hardware e dal software utilizzato per la creazione ed il funzionamento dei documenti digitali, ma ciò non significa che dovrebbero restare fuori dal processo. Dovrebbero sentirsi liberi di formulare le loro richieste e di mettere in guardia circa il pericolo di perdita di documenti e informazioni. Le soluzioni di qualità dei problemi sono possibili solo sulla base della stretta collaborazione dei gestori della documentazione, degli archivisti e degli specialisti nel settore delle tecnologie dell'informazione.

Parole chiave: documento elettronico, documento in formato elettronico, gestione documentale, scarto, stoccaggio

Upravljanje, valorizacija in ohranjanje elektronskih zapisov: beloruske izkušnje

\section{IZVLE $\check{C} E K$}

Članek je posvečen novim izzivom, $s$ katerimi se arhivi soočajo v zadnjih dvajsetih letih: kako upravljati z e-gradivom, kakšna so načela in merila za njegovo valorizacijo, kako prevzeti najdragocenejše e-gradivo $\mathrm{v}$ arhive in kako zagotoviti njihovo dolgoročno hrambo. Avtor navaja rešitve omenjenih težav, ki so vključene v nacionalni zakonodaji ter razkriva tehnike in prakse, ki se uporabljajo. Kljub velikemu številom zakonodajnih aktov pa težave še vedno ostajajo. Avtor ugotavlja, da so arhivisti pri svojem delu z e-gradivom močno odvisni od strojne in programske opreme, ki se uporablja za ustvarjanje in upravljanje z e-gradivom, vendar to ne pomeni, da bi morali ostati izven tega procesa. Morali bi izražati svoje potrebe in opozarjati na nevarnost izgube dokumentov in informacij, če njihovo mnenje ne bo upoštevano. Kakovostne rešitve te problematike so možne le na podlagi tesnega sodelovanja med vodstvenim kadrom, arhivisti in strokovnjaki s področja informacijskih tehnologij.

Ključne besede: elektronski zapis, zapis v elektronski obliki, upravljanje z dokumentarnim gradivom, valorizacija, hramba 
Andrei RYBAKOU: Management, Appraisal and Preservation of Electronic Records: the Belarusian Experience, 61-70

Кіраванне, экспертыза каштоўнасці і арганізацыя захоўвання электронных дакументаў: беларускі вопыт

\section{РЭЗЮМЭ}

Артыкул прысвечаны новым выклікам, з якімі сутыкнуліся архівы ў апошнія дваццаць гадоў: як кіраваць электроннымі дакументамі, якія прынцыпы і крытэрыі экспертызы іх каштоўнасці, як перадаваць найбольш каштоуныя электронныя дакументы ў архіў і забяспечваць іх доўгатэрміновае захоўванне. Аўтар распавядае пра замацаваныя ў нацыянальным заканадаўстве падыходы да вырашэння згаданых праблем, раскрывае адпаведныя методыкі, што выкарыстоўваюцца на практыцы. Нягледзячы на велізарную колькасць актаў заканадаўства, праблемы ўсё роўна застаюцца. Аўтар звяртае ўвагу, што архівісты ў працы з электроннымі дакументамі моцна залежаць аА тэхнічнага і праграмнага забеспячэння, якое выкарыстоўваецца дмя стварэння і функцыянавання электронных дакументаў, але гэта не азначае, што яны павінны заставацца паза межамі працэсу. Яны павінны смела выказвць свае патрабаванні і папярэджваць аб небяспецы страты Аакументаў і інфармацыі, калі яны будуць ігнаравацца. Якаснае рашэнне праблем магчыма толькі на аснове цеснага супрацоўніцтва кіруючых дакументамі, архівістаў і спецыялістаў у галіне інфармацыйных тэхналогій.

КАючавыя словы: электронны Аакумент, дакумент у электронным выглядзе, кіраванне документамі, экспертыза каштоўнасці, арганізацыя захоўвання

\section{Introduction}

Before we start consideration of the range of issues named in the article title, we must define the content of "electronic records" (E-records) concept.

In general we shall understand a record as the information fixed on a material carrier, which was created or received and maintained by the state body, organization, enterprise (hereafter "organization") for the evidentiary or reference purposes in pursuance of legal obligations or in the transaction of business activity. This information should have data information elements (requisites, metadata) which allow to identify it and, accordingly, to perceive and process it as a unit (СТБ 2059-2013, p.3.1.3, ISO 15489-1:2001(E), p. 3.15).

The specific feature of an E-record is that its information is presented on the material carrier in the electronic digital form. Today the information technologies, allowing recording the information in the electronic digital form, are applied practically in all fields of activity. Therefore in a general sense E-records include the documents created in the administrative activity of organizations (administrative records), film documents, photographic documents and phonodocuments (audio-visual records), technical documentation, information resources (databases and databanks), etc. All these documents can initially be created in the electronic digital form (digitally-born records) or transformed into digital form from paper or other traditional medium (for example, microfilm) by means of scanning equipment (for example, electronic copies of paper-born records).

This article considers managerial records, included in the organization's records system. The problems of management, appraisal and preservation of both digital- born records and electronic copies of paper-born records created in the administration process are analysed.

Organization of work with other E-records (technical, audio-visual, medical, etc.) has its own specific features, it is regulated by special rules, and specialised archives are created as a rule for their storage. Therefore this article do not consider them, as well as electronic copies of records on paper and other material carriers created in the state archives for the purpose of preservation of existing paper originals during its use and/or provision of more convenient access of users to archival records, including that via Internet.

\section{Legislative bases of electronic records management}

In Belarus the issues of creation and sphere of application of E-records are stipulated in a wide range of regulatory legal acts. 
Among them Law of the Republic of Belarus On Electronic Record and Electronic Digital Signature is a framework act. According to this law the E-record is a document in electronic form with the requisites which allow establishing its integrity and authenticity (Закон Республики Беларусь Об электронном документе и электронной цифровой подписи, 2009, art. 1). Such requisite under the law is the electronic digital signature (EDS), which is attached as a separate file to the record contents file. Besides the E-record should be created, processed, stored, transferred and received by means of hardware, software and soft hardware and also be presented in an acceptable and clear form for human perception (Закон Республики Беларусь Об электронном документе и электронной иифровой подписи, 2009, art. 16, 17).

Once the E-record corresponds to the statutory requirements it is equated to the paper-record signed in person and has identical validity (Закон Республики Беларусь Об электронном документе и электронной цифровой подписи, 2009, art. 2). The law stipulates that E-records can be used in all fields of activity where they use hardware, software and soft hardware required for creation, processing, storage, transmission and reception of information in electronic form (Закон Республики Беларусь Об электронном документе и электронной цифровой подписи, 2009, art. 15).

Thus, the law makes distinction between two concepts: electronic record and record in electronic form. The record in electronic form is any document the information of which is presented in the electronic digital form. It can contain any digital signature (for example, EDS or scanned image of the signature from paper) or be unsigned. The electronic record is only the document in electronic form which is certified by EDS.

Opportunities of application of E-records and records in electronic form in specific fields of activity are also regulated by a number of special legislative acts establishing or detailing certain requirements to such documents. For example, there are separate acts in the sphere of state electronic registration of business entities, financial, bank, tax spheres, etc.

Provisions of Law on Electronic Record and Electronic Digital Signature which vest the bodies on archives and records management and state archival institutions with authority in the sphere of circulation of E-records and electronic digital signature are essentially important. According to the law archival bodies and establishments:

- carry out development and implementation of a unified state policy in the sphere of acquisition of the National Archival Fond of the Republic of Belarus with E-records, their preservation, organization of their stock-taking and use;

- effect control over the observance of the legislation of the Republic of Belarus in the sphere of archives and records management in dealing with E-records and its methodological support (Закон Республики Беларусь Об электронном документе и электронной цифровой noдnuсu, 2009, art. 12).

It should also be noted that according to Law of the Republic of Belarus On Archival Work and Records Management in the Republic of Belarus the national regulatory body in the sphere of archives and records management is vested with powers of development and implementation of a unified state policy in the sphere of archives and records management, and also on introduction of unified principles of organization of archives and records management (Закон Республики Беларусь Об архивном деле и делопроизводстве в Республике Беларусь, 2011, art. 6). The regulatory body in the sphere of archives and records management is the Ministry of Justice of the Republic of Belarus, which includes the Department on Archives and Records Management.

On this basis the Ministry of Justice of the Republic of Belarus approved the Instruction on Records Management in the State Bodies and Other Organizations (hereafter the Instruction on Records Management) which has established general requirements to records management in the country, including the issues relating to the specific features of the work with records in electronic form (Инструкиия по делопроизводству в государственных органах, иньхх организациях, 2012). The requirements to the management of records in electronic form are stipulated in the Instruction on Records Management in a separate Chapter 18 Specific Features of Work with Records in Electronic Form. 
Attention should be paid to the fact that the provisions of the Instruction on Records Management cover all records in electronic form and not just electronic records with EDS. This is because the Civil Code of the Republic of Belarus permits to use not only EDS, but also other analogues of the autograph signature in the transactions between the parties (organizations, citizens) made according to the legislation or preliminary agreement (Гражданский кодекс Республики Беларусь, 1998, art. 161). Therefore the Instruction on Records Management provides the opportunity of use in operative management and information exchange between the organizations, of records in electronic form not certified by EDS, if the software of organizations allows identification of management and information exchange participants and the parties recognise such documents.

Thus, the Instruction on Records Management permits to use in records management of organizations both digitally-born records and electronic copies of paper-born records (scans). In this regard any of them can be certified either by EDS or by other digital signature, or else be without a digital signature at all.

\section{Technology of electronic records management}

The Instruction on Records Management stipulates that the formats of records in electronic form, as well as the types of tangible media used for their storage are defined by the organization if the Belarusian legislation does not stipulate otherwise. The formats used should provide authenticity, accessibility, integrity of the information of records in electronic form and complete data on the ways of their creation, transmission (receipt, sending), storage from the moment of their creation (receipt) till their transfer to archive or destruction, including that in converting of records to new formats, migration in new automated systems, export from electronic mailing system, etc.

Admissible formats of records in electronic form are:

Portable Document Format / A (PDF/A);

Office Open XML (DOCX);

Open Document Format (ODT).

Admissible formats of graphic images of documents on paper (scans) are:

Portable Network Graphics (PNG);

Tagged Image File Format (TIFF);

Joint Photograph Experts Group (JPEG);

Portable Document Format / A (PDF/A).

In this regard the organizations being the sources of acquisition of the state archives should coordinate the formats used for records in electronic form, with the authorized state archival establishment.

The record in electronic form should have all the requisites established for the similar document on paper, except for graphically made requisites (for example, impressions of seals and stamps). The arrangement and appearance of requisites in the record in electronic form at its external representation $^{1}$ should correspond to the requirements set for similar paper records.

EDS should be used as an equivalent of the autograph signature in creation of records. At the same time organizations can set up the rules of signing, coordination and approval of internal records in electronic form (with some exceptions) without EDS use. Such rules can be established on condition that the software used in the organization, allows clear identification of the person who has signed (coordinated, approved) the document.

Signing of outgoing (sent) documents without EDS is admitted under the agreement of parties provided that the software applied in the organizations, allows clear identification of the person or the organization - the author of the document.

1.External representation of the record in electronic form is its reproduction on an electronic display, on paper or other tangible media in the form accessible and comprehensible for human perception. 
The Instruction on Records Management stipulates that registration, reception and sending of records in electronic form should be carried out in the same way as reception and sending of paper documents: centrally (records management service, the secretary, etc.). At the same time receipt and sending of some records in electronic form is admitted for structural divisions (officers) of the organization without participation of records management service. In doing this, the organization should develop for this purpose a special list of categories of documents in electronic form, receipt and sending of which is carried out by structural divisions (officers) of the organization independently.

Upon receipt of the documents signed with EDS, the following is to be checked:

- EDS authenticity;

- conformity of the way of EDS use to the data specified in the signature key certificate;

- validity of the signature key certificate.

Check of the signature key certificate validity includes check of signature key certificate duration (the term of the signature key certificate should not expire at the moment of signing the document), and also the receipt from the certificating centre which has issued the signature key certificate, of data on action of the signature key certificate (valid, suspended, terms of suspension, cancelled).

It should be noted that in internal and outgoing records in electronic form certified with EDS, requisites "Date" and "Registration Index" should be filled in after their signing. They are included in a separate file (files). It makes it possible to retain authenticity and integrity of the signed E-record ${ }^{2}$. In internal and outgoing records certified without EDS, requisites "Date" and "Registration Index" are, as a rule, included in the record's source file.

Similar requirements are set for other requisites which accompany with the record during its handling. For example, in incoming and internal records the information containing in requisites "Resolution", "Incoming Stamp" (registration data on the incoming document), other service marks, are not included in source files while handling records in electronic form. This information is entered in paper registration forms (in a registration cards or a log) or in a registration files in database, the management of which is carried out by means of an automated system, and if necessary attached in the form of independent files to the registered (accounted) records.

Registration and accounting data and links between them and records are retained in permanent and accessible form for reproduction and human perception during the whole life cycle of records. The registration and accounting data are transferred together with records in electronic form in case of their transmission inside the organization or sending out.

Records in electronic form, including those sent (received) by e-mail, are admitted to be:

- exported to the electronic files external in relation to mailing system;

- exported to the automated records management system (ARMS);

- printed out on paper.

While sending by e-mail the record in electronic form is attached as an application (file) to the electronic letter (e-mail message). Thus, in transmission of an E-record (record in electronic form) by e-mail the main object of records management is the file attached to the electronic message, and the electronic message has the function of an envelope.

When exporting the record (file) to a file external in relation to mailing system or to ARMS or its printing out the electronic message, as a rule, is not exported or printed out. Exceptions are the cases when the record does not contain requisite "Date" and also when the information of the electronic message $e^{3}$ is required for acknowledgement of the fact and conditions of sending (receipt) of the record and/or can be used for reference and evidential purpose.

2. According to the records-keeping rules any document, either paper or electronic, should be signed first, and only then dated and registered; if the document has already been signed with EDS, inclusion in a source file of the corresponding new information will lead to the loss of its authenticity and integrity.

3. This information includes: data on the electronic address of the sender (recipient), date of sending, date of receipt, the letter subject, data on the ways of passage of the electronic letter via information and communication channels, the letter identifier of in the information system, etc. 
The records in electronic form, including those sent (received) by e-mail, should be made available, during their storage and use to all interested workers of the organization according to the assigned duties and access rights.

Records in electronic form, the work with which is completed, are formed in electronic files (folders, directories on the hard disk of a specially selected computer) according to the filing plan of the organization. All the files, both paper and electronic, are included in the filing plan which is compiled as per the established rules. In doing this, the presence of electronic and hybrid files in the filing plan is mentioned separately.

The requirements to work with hybrid files deserve special attention. Hybrid files are those containing both paper documents and records in electronic form. The Instruction on Records Management permits creation of hybrid files in cases when the documents partly created in the organization as a record in electronic form or received by telecommunication channels and partly received by the organization or created in the organization on paper are united in one file. For example, a hybrid file is formed in the event that the organization has received the letter in electronic form, and the reply was sent out on paper.

Hybrid files are permitted only at the stage of office-work. After the end of the year a hybrid file is to be reformed into either the file with paper records (E-records are printed out and certified) or electronic file (electronic copies of paper-born records are scanned). It makes it possible to provide the file integrity and to preserve the links among its documents irrespective of the way they have been initially created in the organization or received by it.

\section{Appraisal and storage of electronic records}

The same periods of storage as for similar paper documents are established for storage of records in electronic form. This requirement is stipulated in both the Instruction on Records Management and in the List of Typical Documents Created in the Course of Activity of State Bodies, Other Organizations and Individual Entrepreneurs, with the indication of storage periods (Перечень типовых документов Науионального архивного фонда Республки Беларусь, образуюоихся в проиессе деятельности государственньх органов, иньх организачий и индивидуальныхх предпринимателей, $c$ указанием сроков хранения, 2015). Attention should be paid to the fact that norms of the above List are mandatory for use by all organizations of the country, both state and non-state.

According to the legislation all the documents, period of storage of which exceeds 10 years, including documents of permanent storage, should be transferred to organization's archive ${ }^{4}$ (Правилa работы архивов государственньцх органов и иньх организаиии, 2012). Thus, the records in electronic form the storage period of which exceeds 10 years, including those of permanent storage, should be transferred to archive of the organization with perspective of their subsequent transfer to storage in the state archive. According to the Instruction on Records Management the location of storage of electronic files (folders) and separate records in electronic form before their transfer to archive or assignment to destruction is defined by the organization independently and stipulated in a local legal act approved by the head of the organization.

At present only the Belarusian Scientific and Research Centre of Electronic Documents (BelNITsED) may receive records in electronic form for permanent storage; the archive of electronic records is created there for this purpose. Other state archives do not accept records in electronic form for storage (except for the Belarusian State Archive for Cinema-Photo-Phonodocuments, accepting the corresponding documentation for permanent storage).

The storage period of records, including those in electronic form, is established by the results of their appraisal. The Instruction on Records Management provides for appraisal of records in electronic form to be carried out in the same order as appraisal of documents on paper.

Thus, in appraisal of documents irrespective of their carrier (both paper and electronic) the general principles and criteria of appraisal of documents set in the Rules of Archival Work in the State Bodies and Other Organizations should be applied.

4. The archive should be created in each organization as a separate division. 
The records in electronic form obviously have their specific features. For this reason the Ministry of Justice of the Republic of Belarus approved a separate Instruction on the Procedure of Appraisal and Transfer for Permanent Storage of Records in Electronic Form and Information Resources (Инструкция о порядке проведения экспертизы ценности и передачи на постоянное хранение документов в электронном виде и информачионныцх ресурсов, 2012). Provisions of this Instruction are not only limited to the administrative documentation but also cover scientific and technical, geological, telemetric documentation, information resources (databases, web-sites, etc.), cinema-, photo-, phono-, video documents, etc. Specific criteria to be applied at appraisal of records in electronic form were also included, with the following novelties among them:

- integrity of composition of parts and elements of a record in electronic form;

- visual expression of information and convenience of its use comparing with analogues on paper;

- opportunity of permanent storage of records in electronic form;

- opportunity of reproduction and processing of records in electronic form without use of additional specialized software;

- availability of accompanying documentation on the records in electronic form and technological documentation on the information system in which the records have been created and existed.

Besides in the above mentioned Instruction the stages of appraisal of records in electronic form are set out:

Stage 1: during designing (commissioning) of the information system (that is, software) which will be used for creation and/or circulation of records in electronic form, creation and operation of an information resource;

Stage 2: after the period of storage of records in electronic form and information resources in the organization with the purpose of defining the necessity of its transfer to the state archive for permanent storage or assignment to destruction.

Inclusion of the first stage in the procedure of appraisal of records in electronic form seems to be the most important and basic. One of the major features of an electronic record is that it can exist only in the certain information system. Accordingly, if this system cannot provide creation of reproducible and suitable for permanent and long (over 10 years) storage of records in electronic form, the subsequent transfer of such records for storage in archive becomes impossible either. It means that the record containing valuable information will eventually be irrevocably lost.

The Ministry of Justice also approved, simultaneously with the above Instruction, the Instruction on the Order of Organization of the Work with Records in electronic Form in Archives of State Bodies and Other Organizations (Инструкция о порядке организации работы с документами в электронном виде в архивах государственньцх органов, иньх организачи, 2012). It does not contain any special requirements to work with records in electronic form. The important provision in it is that records in electronic form should be transferred in archive of the organization one year after completion of its circulation in records management.

We should also note that records in electronic form should be transferred for storage in the state archive not later than in 3 years, which is stipulated in Law on Archives and Records Management (Закон Республики Беларусь Об архивном деле и делопроизводстве в Республике Беларусь, 2011, art. 20).

\section{Problems}

1. Law On Electronic Record and Electronic Digital Signature equalize in rights the paper record and the record in electronic form signed with EDS. At the same time the Instruction on Records Management stipulates that storage of records in electronic form without printing out of original copies on paper, duly issued and signed, is permitted only for the documents with a storage period up to 10 years. Moreover, according to the changes introduced in the Instruction in December, 2014, the detailed list of documents is compiled, creation and storage of which can be organised in electronic form - a total of 303 kinds of documents. 
Thus, all the administrative documents which have not been included in the above mentioned list (and these are all documents, the storage normative period of which exceeds 10 years, including documents of permanent storage), should be initially created and further stored exclusively on paper. In practice the sphere of application of provisions of Law On Electronic Record and Electronic Digital Signature is limited only to administrative documents with a storage period up to 10 years, and also scientific and technical, medical, cine-, photo-, phonodocuments, other special documentation systems. No wonder that today the Archive of Electronic Documents of the BelNITsED has practically anything to be completed. A great bulk of the documents stored there are archival copies of information resources (databases, web-sites, etc.), and also documents of temporary storage.

One of the reasons of introduction of such restriction in the sphere of use of electronic documents is the concern of archival bodies and establishments with regard to the possibility to preserve them in the longer term with observance of their authenticity and integrity, and accordingly, their evidential effect. The problems existing in this sphere are well-known and described in special literature (Rybakou, 2012).

2. The approach incorporated in the Instruction on Records Management to the possibility of creation and storage of administrative records exclusively in electronic form actually provides for appraisal of the document at a stage of its creation. However, archivists know very well that one can make an impartial assessment of scientific, historical, political, economic, social, cultural importance of the document only eventually on the basis of comprehensive application of appraisal principles and criteria. The initial estimation of the E-record as having merely practical value and consequently referred to the category of temporary (up to 10 years) storage, can change: the document can be recognized as having scientific and historical value and, accordingly, subject to permanent storage in archive. Therefore the problem of long-term preservation of the E-record remains topical.

3. The major characteristics of E-record are: digital form of information presentation; its existence only in the certain system; presence of content and metadata. In this connection none of techniques of reception of E-records for archival storage tested at present and the organization of such storage are ideal. The use of a "container method" of E-record transfer for archival storage leads to its extraction from the software environment of the system in which it was created and handled. Further re-recording of the information can result in the loss of its authenticity. Use of cloud technologies for electronic record storage implying organization of storage of the whole array of electronic records created in a common software environment, on a single carrier, is a very expensive solution. Besides, introduction of cloud technologies for these purposes is connected with the necessity of unification of all software of electronic records circulation participants. One more drawback of such approach is that cloud technologies do not allow quality appraisal of E-records, their selection and subsequent transfer for storage in the state archives. With cloud technologies used for long-term storage of E-records complexity arises with the organization of account of records (defining storage units and their accounting).

\section{Conclusion}

Certain success has been achieved in the spheres of introduction of E-records and ARMS in Belarus in recent years. These processes get significant support at the state level; a set of legislative acts and methodological documents regulating corresponding legal relations has been developed.

However, the issues of efficiency increase of functioning of E-records and ARMS are being solved rather successfully right up to that stage when it concerns organization of long-term storage. For the moment there are no technologies capable of ensuring preservation, integrity, invariance and authenticity of E-records and other documents in electronic form for some longer term. The complexities in solution of this problem are caused by on-going changes of hardware, technologies, types of carriers, and software. These factors are the reason of the loss of data while re-recording the documents in electronic form to new carriers, its migration in the new automated systems, and also while converting into new formats.

In the conditions of absence of unambiguous technological solutions enabling to provide longterm preservation, it is not correct to demand from archival bodies the development of ideal techniques of admission of E-records for long-term storage, including permanent one, with their subse- 
quent fixation in regulatory legal acts. Archivists should lean on technological solutions of this problem in the development of techniques of admission of E-records and organisation of their storage in archives, however purely technological aspects are outside of their competence. At the same time archivists should not stand aside, they should highlight their requirements to the processes of electronic documenting; warn about possible loss of the documents and information in longer term.

In this connection the approach of archival service of the Republic of Belarus to inclusion in electronic records circulation at an initial stage only records of temporary storage (up to 10 years), that is the documents having merely practical value, which they lose after completion of their operative use, appears to be justified. It is reasonable so far to create on paper the records which can be demanded in longer prospect and subject to storage in archive.

\section{Reference list}

1. СТБ 2059-2013 Государственный стандарт Республики Беларусь. Аелопроизводство и архивное дело. Термины и определения. (2013). Минск: Госстандарт

2. ISO 15489-1:2001(E) International standard. Information and documentation - Records management - Part 1: General. (2001). Available at http://www.wgarm.net/ccarm/docs-repository/ISO-15489-Information-anddocumentation\%E2\%80\%93records-management.html (accessed on 28.05.2015).

3. Закон Республики Беларусь Об электронном документе и электронной иифровой подписи. (2009). Available at http://pravo.levonevsky.org/bazaby/zakon/zakb0709.htm (accessed on 28.05.2015).

4. Закон Республики Беларусь Об архивном деле и делопроизводстве в Республике Беларусь. (2011). Available at http://pravo.newsby.org/belarus/zakon0/z194.htm (accessed on 28.05.2015).

5. Инструкиия по делопроизводству в государственньх органах, иньх организачиях (2012). Минск: БеАНИИААА.

6. Гражданский кодекс Республики Беларусь. (1998). Available at http://www.pravo.by/world_of_law/text. asp? $\mathrm{RN}=\mathrm{hk} 9800218$ (accessed on 28.05.2015).

7. Перечень типовьх документов Начионального архивного фонда Республики Беларусь, образующихся в прочессе деятельности государственных органов, иньх организачий и индивидуальньх предпринимателей, $c$ указанием сроков хранения. (2015). Минск: БелНИИААА.

8. Правила работы архивов государственных органов и иных организачий. (2012). Минск: БеАНИИААА.

9. Инструкиия о порядке проведения экспертизы ценности и передачи на постоянное хранение документов в электронном виде и информационных ресурсов. (2012). Национальный реестр правовых актов Респубцики Бемарусь, N. 58.

10. Инструкция о порядке организачии работы с документами в электронном виде в архивах государственньх органов, иных организаций. (2012). Национальный реестр правовых актов Республики Беларусь, N. 58.

11. Rybakou, A. (2012). The expierence of managering documents on new media in Belarus: modern challenges to archives. In: Atlanti: Review for modern archival theory and practice, vol. 22, N. 2, pp. 17-28.

\section{SUMMARY}

Record is the information fixed on a material carrier, which was created or received and maintained by the state body, organization, enterprise for the evidentiary or reference purposes in pursuance of legal obligations or in the transaction of business activity. The major characteristics of E-record are: digital form of information presentation; its existence only in the certain system; presence of content and metadata. According to Law of the Republic of Belarus On Electronic Record and Electronic Digital Signature the E-record is a document in electronic form with the requisites which allow establishing its integrity and authenticity. Such requisite under the law is the electronic digital signature (EDS), which is attached as a separate file to the record contents file. The law makes distinction between two concepts: electronic record and record in electronic form. The record in electronic form is any document the information of which is presented in the electronic digital form. It can contain any digital signature or be unsigned. The E-record is only the document in electronic form which is certified by EDS. Though according to the Law only E-records are equal to paper-records, Belarusian legislation permits to use in practice both E-records and records in electronic form. It stipulates the admissible formats of 
Andrei RYBAKOU: Management, Appraisal and Preservation of Electronic Records: the Belarusian Experience, 61-70

them, rules and requirements to management and appraisal of them. But for the moment there are no technologies capable of ensuring preservation, integrity, invariance and authenticity of E-records and other documents in electronic form for some longer term. In this connection the approach of archival service of the Republic of Belarus to inclusion in electronic records circulation at an initial stage only records of temporary storage (up to 10 years), that is the documents having merely practical value, which they lose after completion of their operative use, appears to be justified. It is reasonable so far to create on paper the records which can be demanded in longer prospect and subject to storage in archive. At the same time archivists should not stand aside, they should highlight their requirements to the processes of electronic documenting; warn about possible loss of the documents and information in longer term.

Typology: 1.04 Professional Article

Submitting date: 30.03 .2015

Acceptance date: 09.04.2015 